\title{
Challenges, Benefits, and Adoption Dynamics of Mobile Banking at the Base of the Pyramid (BOP) in Africa: A Systematic Review
}

\section{Richard Pankomera}

PhD Candidate, School of Information and Communication Technology, Nelson Mandela University, Port Elizabeth, South Africa; and Lecturer, Mzuzu University, Malawi

\section{Darelle van Greunen}

Professor, School of Information and Communication Technology; and Director, Centre for Community Technologies, Nelson Mandela University, Port Elizabeth, South Africa

\begin{abstract}
Increased mobile penetration in Africa offers great potential to accelerate financial inclusion through increased adoption of mobile banking by people at the base of the pyramid (BOP) on the continent. This article provides results from a systematic review of existing research findings on the challenges, benefits and adoption dynamics of mobile banking at the BOP in Africa. The systematic review, which followed PRISMA (preferred reporting items for systematic reviews and meta-analyses) guidelines, identifies the following key challenges for mobile banking diffusion at the $\mathrm{BOP}$ on the continent: poor mobile connectivity; lack of awareness of mobile banking services; illiteracy; poverty; lack of trust due to perceived security risks; legal and regulatory frameworks; and cultural factors. Based on analysis of these challenges, and of the benefits and adoption dynamics also identified, the article provides recommendations on how mobile banking services can be more sustainably implemented for the benefit of people at the BOP in Africa.
\end{abstract}

\section{Keywords}

mobile banking, financial inclusion, base of the pyramid (BOP), Africa; PRISMA (preferred reporting items for systematic reviews and meta-analyses), challenges, benefits, adoption dynamics, technology acceptance model (TAM), unified theory of acceptance and use of technology (UTAUT)

DOI: $\underline{\text { https://doi.org/10.23962/10539/26113 }}$

\section{Recommended citation}

Pankomera, R., \& Van Greunen, D. (2018). Challenges, benefits, and adoption dynamics of mobile banking at the base of the pyramid (BOP) in Africa: A systematic review. The African Journal of Information and Communication (AJIC), 21, 21-49.

https://doi.org/10.23962/10539/26113

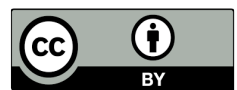

This article is licensed under a Creative Commons Attribution 4.0 International (CC BY 4.0) licence: http://creativecommons.org/licenses/by/4.0 


\section{Introduction}

The rapid spread of mobile devices has engendered a proliferation of mobile banking services throughout the world, with particular significance in African and other developing-world countries where the poorest members of the population have traditionally been unbanked, i.e., have not had a bank account. Accordingly, mobile telephony has contributed to a rise in financial inclusion for disadvantaged people in both developed and developing economies, including many African economies (Demirguc-Kunt, Klapper, Singer, Ansar, \& Hess, 2018). Financial inclusion denotes delivery of financial services-e.g., savings, transactions, payments/transfers, credit, insurance, remittance services-at an affordable cost to disadvantaged and lowincome groups (Kopala, 2010; World Bank, n.d.).

Globally, the percentage of adults who owned a formal bank account rose from $62 \%$ to $69 \%$ between 2014 and 2017. In the developing economies, the rise was from $54 \%$ to 63\% (Demirguc-Kunt, Klapper, Singer, Ansar, \& Hess, 2018). This shows that, starting from a lower base, more people are opening new bank accounts in developing than in developed countries-strong evidence of an increase in developing-world financial inclusion. However, in 2017, it was also estimated that 1.7 billion people in the world did not use formal financial services, and that more than $50 \%$ of adults in the poorest households remained unbanked (Demirguc-Kunt et al., 2018). This indicates that there is still great potential for increased financial inclusion in developing economies.

Most of the people who do not have formal bank accounts are at the base of the pyramid (BOP). According to BOP theory, there is a need to design and distribute affordable goods and services, including financial services targeting specifically the poor communities (Prahalad, 2006). According to the World Bank, 1 in 10 people in the world live under USD1.90, and therefore are considered as falling within the BOP category. Half of these extremely poor people live in Sub-Saharan Africa (The World Bank Group, 2018). Many business entities do not target people at the BOP, on the assumption that most products and services are not sufficiently profitable when delivered to poor communities, as the people in these communities tend not to be able to afford most products and services.

Rural communities in Africa have experienced a considerable proliferation of mobile devices for the past two decades. And Africa has the fastest growth rates in internet penetration, driven by mobile connectivity, with the number of internet users across the continent increasing by more than $20 \%$ in 2017 (Kemp, 2018). There were an estimated 362 million internet users in Africa in January 2017 (Kemp, 2017), and by 31 December 2017, only 12 months later, some estimates were putting the African total at 453 million internet users (World Internet Stats, 2018). West Africa had over 175 million unique subscribers (GSMA, 2018c) while the Middle East and North Africa had over 365 million unique mobile users (GSMA, 2018d) by 2017. 
But in Sub-Saharan Africa, it is estimated that only $44 \%$ of the population had a mobile subscription at the end of 2017 (GSMA, 2018b) and it can be safely assumed that many of the approximately 56\% of Sub-Saharan Africans without mobile subscriptions are living at the BOP.

The main research question for this systematic review was:

- What are the challenges, benefits and adoption dynamics of mobile banking for the people at the BOP in Africa?

Flowing from the research question, the following were the research objectives:

- to identify challenges hindering adoption of mobile banking by people at the BOP in Africa;

- to identify perceived benefits of mobile banking among people at the BOP in Africa; and

- to identify mobile banking adoption dynamics for people at the BOP in Africa.

For the purpose of this research, mobile banking was defined as the use of mobile devices to access bank accounts in order to conduct financial transactions such as verifying account status/balances, money transfer, bill payments (Alafeef, Singh, \& Ahmad, 2012; Lee \& Chung, 2009; Shih, Hung, \& Lin, 2010). Examples of mobile banking services are (Mallat, Rossi, \& Tuunainen, 2004; Porteous, 2006):

- accessing account information such as account balances;

- performing bank account transactions, such as funds transfers between accounts and third-party payments;

- accessing support services such as cheque or card requests; and

- accessing content services such as loyalty-related programmes

The next section provides context in terms of mobile adoption, and mobile banking adoption, in Africa. Section 3 discusses technology adoption theoretical models and mobile banking models, and section 4 outlines our application of the systematic review methodology. Section 5 gives an overview of the studies identified by the systematic review; section 6 discusses and analyses the findings gleaned from the identified studies; and section 7 provides recommendations based on the findings. A conclusion is then provided in section 8 .

\section{Study context}

\section{Mobile adoption in Africa}

GSMA (2018a) reports that the percentage of mobile connections compared to the total population in the Southern Africa, East Africa, West Africa and North Africa is at $147 \%, 61 \%, 89 \%$ and $106 \%$ respectively. This means that there are more connections than the number of people in the Southern Africa and Northern Africa. The percentage of unique mobile users to the total population in the Middle East 
and North Africa is 60\% (GSMA, 2018d), while in Sub-Saharan Africa it is 46\% (GSMA, 2018c). The New 2018 Global Digital Suite reports that Africa experienced a growing number of internet users of $20 \%$ on yearly basis, due to increasingly affordable smart devices and mobile data bandwidth (Kemp, 2018). In addition, the amount of time spent by people online is steadily increasing. The number of social media users in Africa went up by $13 \%$ in the year 2017. In terms of the usage of social media, Facebook is still the most-used social media platform in Africa, followed by YouTube (GSMA Intelligence, 2018).

Steady increases in the usage of mobile applications is being supported by better connection speeds. In 2017, 60\% of African mobile connections were classified as broadband (Kemp, 2018). The mobile broadband connectivity in Southern Africa and East Africa were recently pegged at $83 \%$ and $22 \%$ respectively (GSMA Intelligence, 2018). It must be noted here that much as broadband connectivity offers faster data speeds, mobile banking transactions do not require broadband connectivity, and some can also be done via mobile telephony platforms without internet access.

Although there is promising mobile penetration in Africa, the potential for the usage of mobile technology by rural and poor people at the $\mathrm{BOP}$ remains relatively untapped. GSMA estimates that, at the end of 2017, only 44\% of people in Southern Africa had mobile subscriptions, compared to the $66 \%$ global average (GSMA, 2018b). And that percentage is only expected to rise to $50 \%$ by 2025 (GSMA, 2018b). Most people who remain unconnected are vulnerable groups such as women and youth living in rural communities (GSMA Intelligence, 2016), i.e., people living at the BOP. A 2016 GSMA report cited high costs of mobile connectivity, lack of relevant local content, and high digital illiteracy levels as barriers for mobile penetration in the rural areas of Africa (GSMA, 2016).

\section{Mobile banking adoption in Africa}

The widespread and increasing use of mobile devices in Africa creates expectations that mobile banking adoption can increasingly extend to people at the BOP. By 2017,38\% of the people in the sub Saharan Africa had a broad connection which consequently accelerates digital and financial inclusion (GSMA, 2018b). For instance, there were 135 live mobile money services in 39 countries in Sub-Saharan Africa delivering financial inclusion to the unbanked populations as of 2017 (GSMA, 2018b). It is envisaged that among the estimated 56\% of people in Sub-Saharan Africa who still, at the end of 2017, did not have a unique mobile connection, will in the future become mobile users and be able to benefit from mobile banking technology. Besides mobile connectivity, bank account ownership is one of the factors that influences the adoption of mobile banking. For instance, in Zambia, 20\% of account owners opened their first account to receive digital payments. This implies that ownership of an account is a motivation for embracing digital payment services (Demirguc-Kunt, Klapper, Singer, Ansar, \& Hess, 2018). This is expected to enable people at the BOP 
to increasingly access the financial services in the rural areas (Mbiti \& Weil, 2011; Morawczynski, 2009).

The downsides of traditional banking are that it requires the customer's physical presence at the bank premises, and the presence of bank staff at the branch to engage with the customers and paperwork. It is therefore both time-consuming and manpower dependent (Beck \& Cull, 2013; Chavan, 2013). Therefore, many benefits have been cited for the adoption of mobile banking. Mobile banking makes it easy for the bank account to be accessible at any time from any place in the world, without the account-holder physically visiting the bank branches. This is why mobile banking is also referred to as "branchless banking" (Ivatury \& Mas, 2008).

\section{Theoretical models for technology adoption, and mobile banking models}

Several approaches are cited when studying adoption of technology. One approach, which can be useful when looking at adoption of mobile banking, is to determine the correlation between the adoption of technology and influencing variables such as gender, age, voluntariness of use, and experience (Im, Hong, \& Kang, 2011). Two models that adopt this approach are:

- the technology acceptance model (TAM); and

- the unified theory of acceptance and use of technology (UTAUT)

Other models that can be used in the analysis of adoption of mobile banking are:

- innovation diffusion theory (IDT);

- the information system success model (ISSM);

- the task technology fit (TTF) model; and

- the theory of planned behaviour (TPB).

\section{Technology acceptance model (TAM)}

There are various versions of TAM. The first version (TAM 1) posits that perceived usefulness and perceived ease of use influence users in respect of how and when they use a new technological offering such as mobile banking. Perceived usefulness is "the degree to which a person believes that using a particular system would enhance his or her job performance" (Davis, 1989, p. 320). Perceived ease of use is "the degree to which a person believes that using a particular system would be free of effort" (Davis, 1989, p. 320). A combination of perceived usefulness and perceived ease of use is, in turn, expected to influence behavioural intention to use and actual system use. Figure 1 illustrates TAM 1, in its final version as set out by Venkatesh and Davis (1996). 
Figure 1: TAM 1, as set out by Venkatesh and Davis (1996)

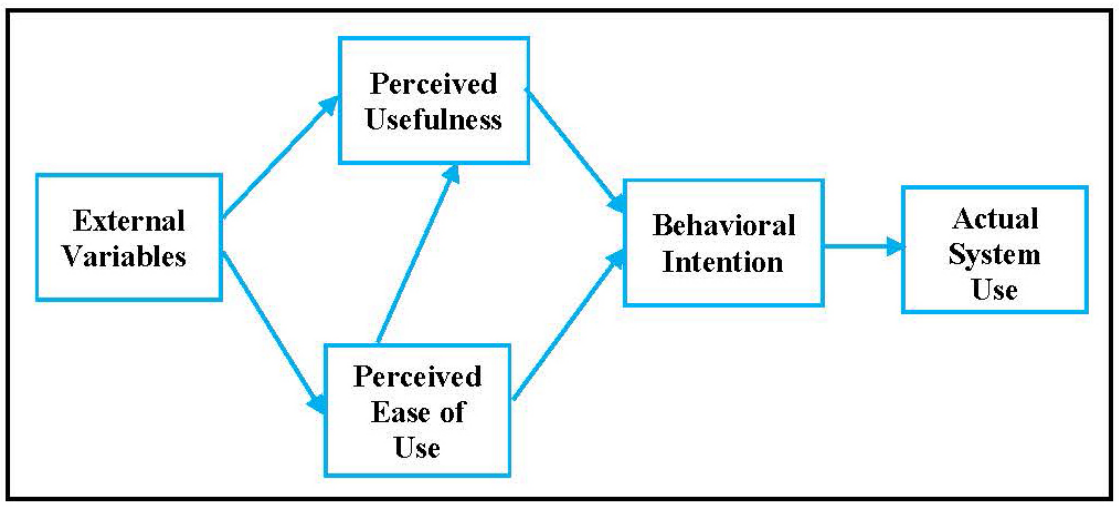

Source : Venkatesh and Davis (1996, p. 453)

TAM 2 introduced additional variables, such as relevance of job, quality of output, demonstrability of the output, image, subjective norm, voluntariness and experience of the user (Venkatesh, 2000). TAM 3 added even more variables: i) Anchor attributes such as computer self-efficacy, perception of external control, computer anxiety and computer playfulness and ii) Adjustments attributes such as perceived enjoyment and objective usability (Venkatesh \& Bala, 2008). By integrating with other constructs, TAM has been used to assess the adoption of mobile banking in real world environment (Gu, Lee, \& Suh, 2009; Rammile \& Nel, 2012; Tobbin, 2012).

\section{Unified theory of acceptance and use of technology (UTAUT)}

UTAUT draws on other models, including TAM and TPB. UTAUT attempts to explain the degree of acceptance of the use of technology with respect to four predictors that may influence users' behaviour and intention: (1) performance expectancy; (2) effort expectancy; (3) social influence; and (4) facilitating conditions. In addition, gender, age, experience, and voluntariness are positioned as influencing the four aforementioned constructs in respect of users' behavioural intention (Venkatesh, Morris, Davis, \& Davis, 2003). Figure 2 below illustrates UTAUT as it is proposed Vankatesh et al. (2003). Many researchers have used UTAUT to determine the factors that influence the adoption of mobile banking (Oliveira, Faria, Thomas, \& Popovič, 2014; Yu, 2012). 
Figure 2: UTAUT, as set out by Venkatesh et al. (2003)

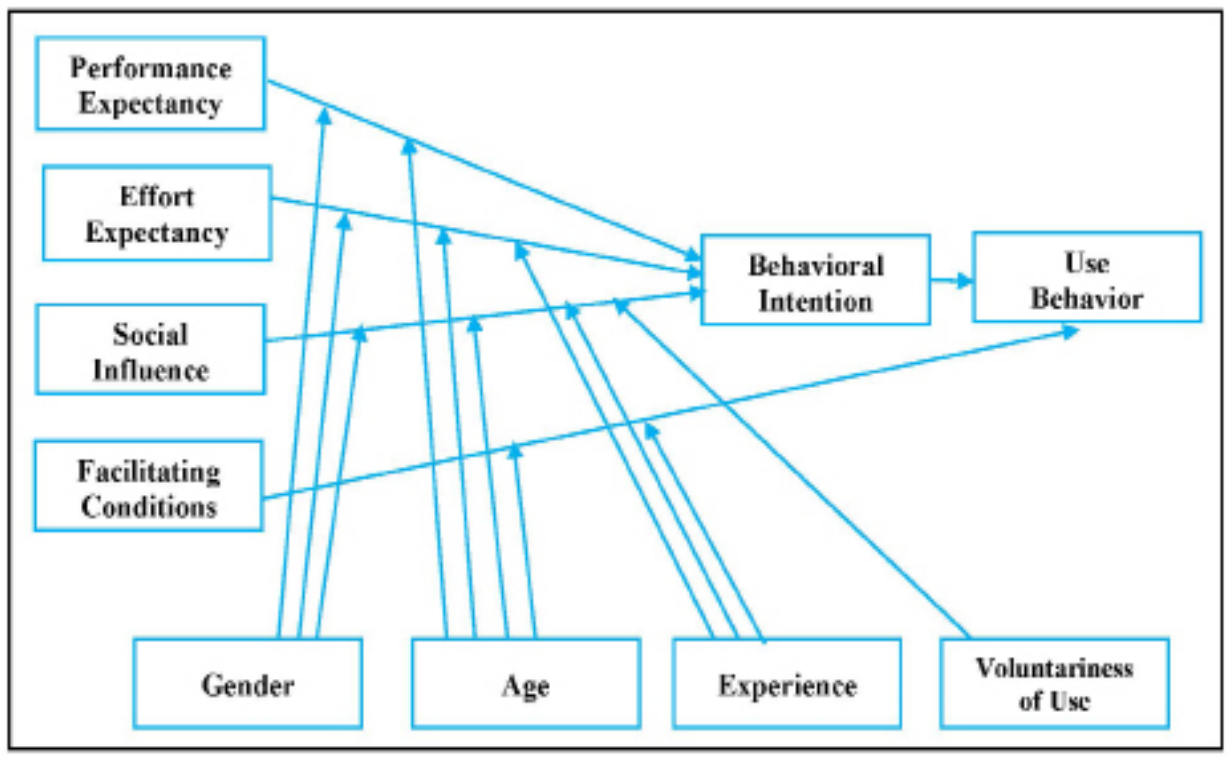

Source: Venkatesh, Morris, Davis and Davis (2003, p. 447)

\section{Innovation diffusion theory (IDT)}

IDT endeavours to explain how, why, and at what rate, innovative new ideas and technology spread (Rogers, 1995). According to IDT, the four main elements that influence the spread of new ideas are: the innovation; communication channels; time; and a social system (Rogers, 1995). In addition, Rogers (1995) argues that there are five categories of adopters, namely: innovators, early adopters, early majority, late majority, and laggards. IDT builds upon Moore and Benbasat (1991) with the following additional characteristics of innovation: relative advantage, ease of use, image, visibility, compatibility, results demonstrability, and voluntary of use. In this case, demonstrability is defined as "tangibility of the results of using the innovation including their observability and communicability" (Moore \& Benbasat, 1991, p. 203). A number of studies have used IDT constructs to interrogate diffusion of mobile banking in developing countries (Brown, Cajee, Davies, \& Stroebel, 2003).

\section{Information system success model (ISSM)}

The ISSM is a model that is used to determine the success of a system based on the following: information quality, system quality, service quality, system use/usage intentions, user satisfaction, and net system benefits. The actual net benefit of the system and user satisfaction are understood as influencing a user's intentions to use a particular system (Delone \& McLean, 2003). ISSM has been used to assess the impact on mobile banking on the livelihood of people (Lee \& Chung, 2009). 


\section{Task technology fit (TTF)}

The TTF model is based on the assumption that there is likely to be a positive impact on individual performance if the capabilities of the technology used match the tasks that the user must perform (Goodhue \& Thompson, 1995). TTF has been widely used to assess success factors and impacts of mobile business applications (Gebauer \& Shaw, 2004; Zhou, Lu, \& Wang, 2010).

\section{Theory of planned behaviour (TPB)}

The TPB states that attitude towards behaviour, subjective norms, and perceived behavioural control all influence an individual's intentions and behaviours (Ajzen, 1985). A number of studies have been conducted that adopt the TPB approach to user behaviour in respect of mobile banking (Nasri \& Charfeddine, 2012; Shih \& Fang, 2004).

\section{Mobile banking models}

(Porteous, 2006) outlines the following four mobile banking models being followed in Africa:

- Pure bank-driven model: In this model, the bank has exclusive control of the deposit account. Therefore, the bank sells its own brand. Additional financial services may be extended to those who hold bank accounts by introducing mobile banking services. This is also called the "additive banking" model as it targets existing bank customers by providing them with better and more convenient banking services through channels such as ATMs and telephonebanking.

- Joint-venture model: The bank still holds ownership of the deposit account, but it goes into partnership with non-bank organisations, e.g., mobile network operators and/or other telecommunications company. Cash can still be accessed at the bank, but the bank can instruct the third party to carry out other payment transactions to the client.

- Non-bank-led model: The bank still takes control of the account, but the brand of a non-bank company (e.g., a mobile network operator or other telecommunications company) becomes dominant. Cash can still be accessed at the bank and any alternative network agent.

- Non-bank-driven model: Unlike the above-listed models, the non-bankdriven model allows non-bank companies (e.g., mobile network operators or other telecommunications companies) to own deposit accounts. The nonbank company can provide a range of financial services to the account-holder, including dispensing cash, and they can promote their own m-banking brands. 


\section{Research outline: The systematic review}

The systematic review was guided by the PRISMA (preferred reporting items for systematic reviews and meta-analyses) framework and used research bibliographic databases such as Scopus and IEEE Xplore. The following were the guiding elements of the review, in line with the PRISMA model (Moher, Liberati, Tetzlaff, \& Altman, 2009):

- inclusion criteria;

- search strategy;

- data collection and extraction;

- assessment of quality; and

- analysis.

\section{Inclusion criteria}

It was determined that the studies considered for inclusion would be from the period 2007 to 2018 and would include literature focused on mobile banking for individuals at the BOP in Africa.

\section{Search strategy}

Published reports, grey literature, peer-reviewed papers, and peer-reviewed journal articles on mobile banking were analysed. Peer-reviewed journal articles were searched in research databases including Scopus, EBSCOhost, and IEEE Xplore. These items identified were narrowed down to those that focused on the challenges and benefits of embracing mobile banking in Africa.

Keywords used to identify studies were: "mobile banking", "cell phone banking", "branchless banking", "BOP", "bottom of pyramid", "base of pyramid", "Africa", "developing countries", "poor economies" and "m-banking". Search keyword connectors such as AND, OR and NOT were used either to narrow or broaden the results.

\section{Data collection and extraction}

The14 studies that were retrieved in line with the inclusion criteria, and the data extracted from the studies, are featured later in this article in sections 5 and 6.

\section{Assessment of quality}

The data gathered in the previous steps were checked and verified by an independent researcher experienced in both qualitative and quantitative research. This process ensured the credibility of studies selected and ensured that the selected studies met the inclusion criteria.

\section{Analysis}

Figure 3 depicts the sequence of steps followed in the systematic review process. The titles and abstracts of the studies that met the criteria were scrutinised. Duplicates 
were subsequently excluded, generating a total of 53 studies. Of those, 39 were excluded on the grounds that: some did not specifically focus on mobile banking; some only focused on mobile banking activities in developed countries; some looked at mobile banking in developing countries but not in Africa; some looked at mobile banking interventions that were not specifically targeting people at the BOP in Africa. Finally, 14 studies were identified for review.

Figure 3: PRISMA systematic review flowchart for the study

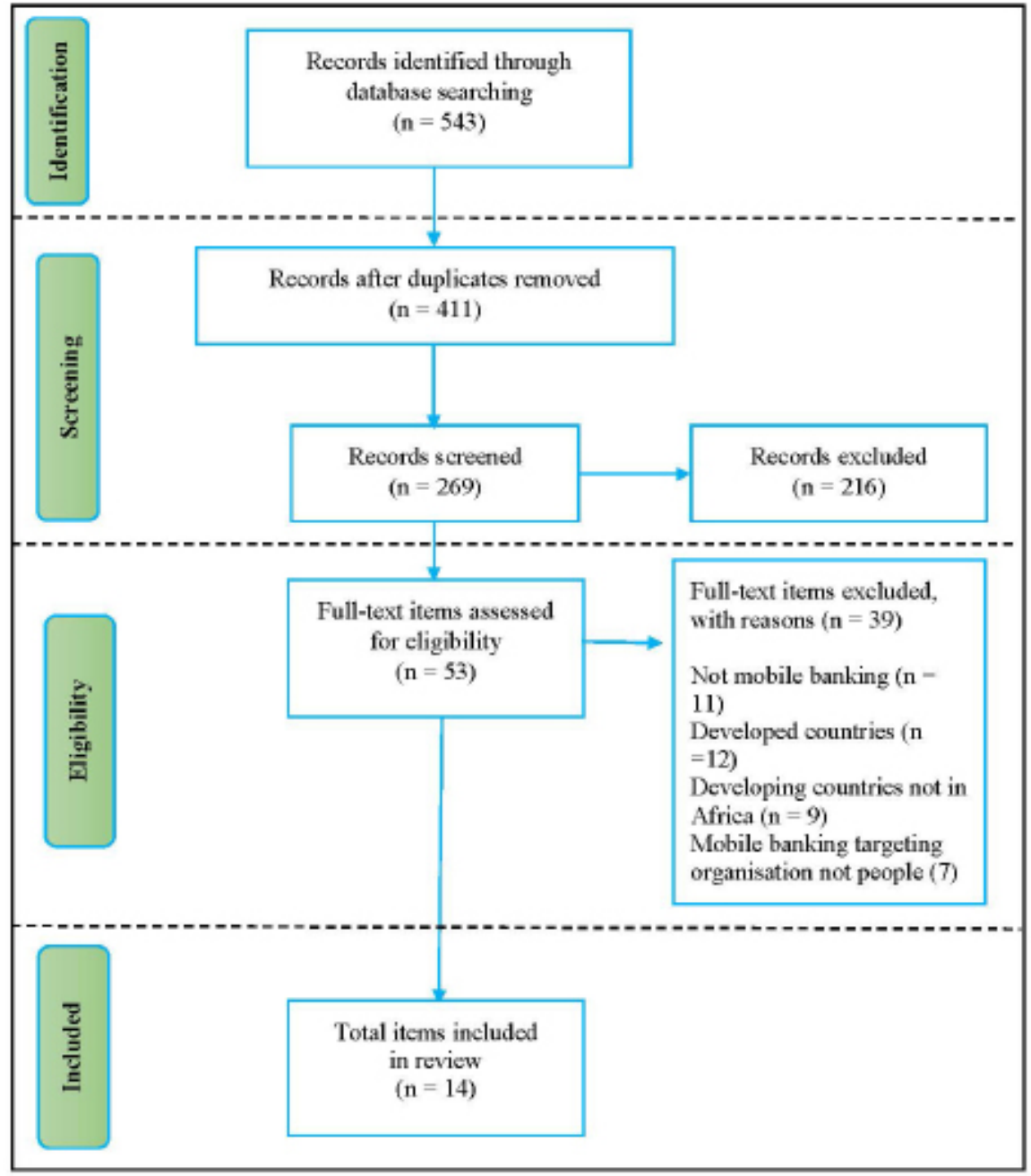

Source: based on flowchart in Moher, Liberati, Tetzlaff, and Altman (2009) 


\section{Studies selected via the systematic review}

\section{Study countries, regions}

Twelve of the studies, collectively, look at mobile banking several individual countries-Nigeria, Zimbabwe, Sudan, Rwanda, South Africa, Malawi, Ghana, Zambia, Kenya, Mozambique-and two of the studies take a much broader approach, looking at mobile banking in Sub-Saharan Africa, and almost all of Africa (49 African countries), respectively.

\section{Studies'foci}

Eleven of the 14 studies focus on at least three of the following mobile-banking user dimensions: age group, gender, income level, education level, residence area, ownership of mobile device, experience of mobile device usage, perceived benefit, perceived ease of use of mobile banking, perceived usefulness of mobile banking, and social and cultural aspects of using mobile banking.

\section{Studies'methods}

Across the studies selected, both quantitative and qualitative methods are employed. Four studies use only quantitative methods, and three used only qualitative methods. The other seven studies use a mix of quantitative and qualitative methods. Many of the studies use survey questionnaires, and semi-structured face-to-face interviews, focus groups, and telephone interviews are also frequently used. Some studies make use of data sets from the International Telecommunication Union (ITU) and Global Information Society Watch.

Table 1, provided over the next three pages (pp. 32-34), presents an overview of the 14 studies from which data were obtained and analysed. 
Table 1: The 14 selected studies

\begin{tabular}{|c|c|c|c|}
\hline $\begin{array}{c}\text { Author(s) } \\
\text { (year): } \\
\text { Country(ies), } \\
\text { region }\end{array}$ & $\begin{array}{l}\text { Objective(s), } \\
\text { research } \\
\text { question(s) }\end{array}$ & $\begin{array}{l}\text { Theories, } \\
\text { models }\end{array}$ & Data collection \\
\hline $\begin{array}{c}\text { Chukwumah } \\
\text { (2017): } \\
\text { Nigeria }\end{array}$ & $\begin{array}{l}\text { - What factors } \\
\text { influence } \\
\text { adoption of } \\
\text { mobile banking } \\
\text { in rural } \\
\text { Nigeria? }\end{array}$ & - TAM & $\begin{array}{l}\text { - } 186 \text { questionnaire respondents in } \\
\text { four villages in Katsina } \\
\text { - Respondents' gender: M (44\%), F } \\
\text { ( } 56 \%) \\
\text { - Ages: } 84 \% \text { between } 20 \text { and } 49,37 \% \\
\text { between } 30 \text { and } 39 \\
\text { - Education: } 33 \% \text { with only primary } \\
\text { school } \\
\text { - Occupations: retailers (52\%), farmers } \\
\text { ( } 20 \%) \\
\text { - Monthly income: } 53 \% \text { less than } \\
\text { 5,000 Naira ( } 36.5 \text { USD) } \\
\text { - Mobile phone ownership: } 59 \% \\
\text { - More than three years of use of using } \\
\text { mobile phone } 26 \%\end{array}$ \\
\hline $\begin{array}{l}\text { Mago and } \\
\text { Chitokwindo } \\
\text { (2014): } \\
\text { Zimbabwe }\end{array}$ & $\begin{array}{l}\text { To evaluate } \\
\text { the impact of } \\
\text { mobile banking } \\
\text { as a financial } \\
\text { inclusion } \\
\text { strategy }\end{array}$ & $\begin{array}{l}\text { Joint-venture } \\
\text { model of } \\
\text { mobile banking }\end{array}$ & $\begin{array}{l}\text { - } 270 \text { survey respondents in Chivi, } \\
\text { Bikita, Gutu and Masvingo } \\
\text { - Income level data collected to } \\
\text { determine possible influence on } \\
\text { adoption of mobile banking }\end{array}$ \\
\hline $\begin{array}{c}\text { Ammar } \\
\text { and Ahmed } \\
\text { (2016): } \\
\text { Sudan }\end{array}$ & $\begin{array}{l}\text { To examine } \\
\text { the factors } \\
\text { that influence } \\
\text { adoption } \\
\text { of mobile } \\
\text { banking in the } \\
\text { microfinance } \\
\text { sector in Sudan }\end{array}$ & $\begin{array}{l}\text { - UTAUT and } \\
\text { technology } \\
\text { organisation- } \\
\text { environment } \\
\text { (TOE) }\end{array}$ & $\begin{array}{l}\text { - } 393 \text { survey respondents } \\
\text { - Respondents' gender: M (43\%), F } \\
\text { ( } 57 \%) \\
\text { - Age: } 35 \% \text { aged } 28-37 \\
\text { - Education: } 91 \% \text { literate } \\
\text { - Mobile phone ownership: } 99 \% \\
\text { - Frequency of mobile usage: } 85 \% \\
\text { daily } \\
\text { - Duration of mobile experience: } 61 \% \\
\text { with 6-8 years of experience }\end{array}$ \\
\hline $\begin{array}{l}\text { Van der } \\
\text { Wansem } \\
\text { (2013): } \\
\text { Rwanda }\end{array}$ & $\begin{array}{l}\text { To research } \\
\text { how mobile } \\
\text { banking } \\
\text { has affected } \\
\text { financial } \\
\text { inclusion, in } \\
\text { terms of access } \\
\text { and usage } \\
\text { of financial } \\
\text { services, with } \\
\text { a distinction } \\
\text { between rural } \\
\text { and urban areas }\end{array}$ & $\begin{array}{l}\text { Pure bank- } \\
\text { driven model } \\
\text { of mobile } \\
\text { banking }\end{array}$ & $\begin{array}{l}\text { - } 240 \text { respondents to telephone survey } \\
\text { - } 5 \text { focus groups from } 5 \text { locations: } \\
\text { Kigali-East (7 participants), Kigali- } \\
\text { West (17 participants), Musanza } \\
\text { (15 participants), Cyanika (20 } \\
\text { participants) and Ruhuha (12 } \\
\text { participants) }\end{array}$ \\
\hline
\end{tabular}




\begin{tabular}{|c|c|c|c|}
\hline $\begin{array}{l}\text { Author(s) } \\
\text { (year): } \\
\text { Country(ies), } \\
\text { region }\end{array}$ & $\begin{array}{l}\text { Objective(s), } \\
\text { research } \\
\text { question(s) }\end{array}$ & $\begin{array}{l}\text { Theories, } \\
\text { models }\end{array}$ & Data collection \\
\hline $\begin{array}{c}\text { Bankole and } \\
\text { Cloete (2011): } \\
\text { South Africa, } \\
\text { Nigeria }\end{array}$ & $\begin{array}{l}\text { - To examine } \\
\text { differences and } \\
\text { similarities } \\
\text { between mobile } \\
\text { banking usage } \\
\text { in South Africa } \\
\text { and Nigeria }\end{array}$ & - UTAUT & $\begin{array}{l}\text { - } 451 \text { questionnaire respondents: in } \\
\text { South Africa (220) and Nigeria (231) } \\
\text { - } 10 \text { face-to-face interviews each in } \\
\text { South Africa and Nigeria respectively } \\
\text { (6 males and } 4 \text { females interviewed } \\
\text { from each country) }\end{array}$ \\
\hline $\begin{array}{l}\text { Mtambalika, } \\
\text { Manda, } \\
\text { Gombachika } \\
\text { and Kunyenje } \\
\text { (2016): } \\
\text { Malawi }\end{array}$ & $\begin{array}{l}\text { - To examine } \\
\text { readiness of } \\
\text { the bank-led } \\
\text { "branchless } \\
\text { banking" } \\
\text { mobile banking } \\
\text { model for } \\
\text { outreach to } \\
\text { unbanked rural } \\
\text { areas in Malawi }\end{array}$ & $\begin{array}{l}\text { - Pure-bank- } \\
\text { driven model } \\
\text { - TAM }\end{array}$ & $\begin{array}{l}\text { - } 210 \text { completed questionnaires in } 5 \\
\text { Traditional Authorities-Msundwe, } \\
\text { Kalolo, Mduwa, Mavwere and } \\
\text { Mlonyeni-in Lilongwe and Mchinji } \\
\text { districts }\end{array}$ \\
\hline $\begin{array}{c}\text { Hinson } \\
\text { (2011): } \\
\text { Ghana, Africa }\end{array}$ & $\begin{array}{l}\text { To } \\
\text { conceptualise a } \\
\text { mobile banking } \\
\text { model for } \\
\text { the poor in } \\
\text { developing- } \\
\text { economy } \\
\text { contexts }\end{array}$ & $\begin{array}{l}\text { Joint-venture } \\
\text { model of } \\
\text { mobile banking }\end{array}$ & $\begin{array}{l}\text { - Literature review on mobile baking } \\
\text { for the poor in Ghana and Africa }\end{array}$ \\
\hline $\begin{array}{l}\text { Tchouassi } \\
\text { (2012): } \\
\text { 30 Sub- } \\
\text { Saharan } \\
\text { African } \\
\text { countries }\end{array}$ & $\begin{array}{l}\text { - To identify } \\
\text { effects of } \\
\text { mobile phones } \\
\text { on the rate } \\
\text { of banking } \\
\text { adoption }\end{array}$ & $\begin{array}{l}\text { - Contestable } \\
\text { market theory }\end{array}$ & $\begin{array}{l}\text { - Data from ITU, and from reports by } \\
\text { Global Information Society Watch, } \\
\text { on } 30 \text { Sub-Saharan African countries } \\
\text { - Independent variables: income, age } \\
\text { group, urban or rural area }\end{array}$ \\
\hline $\begin{array}{l}\text { Van der Boor, } \\
\text { Oliveira and } \\
\text { Veloso (2014): } \\
\text { Zambia, } \\
\text { Kenya }\end{array}$ & $\begin{array}{l}\text { To examine } \\
\text { factors } \\
\text { that enable } \\
\text { innovation in } \\
\text { mobile banking } \\
\text { services in } \\
\text { developing } \\
\text { countries }\end{array}$ & - Not specified & $\begin{array}{l}\text { - Historical analysis of company } \\
\text { reports, news articles, case studies, } \\
\text { documents by vendors, on mobile } \\
\text { banking } \\
\text { - Interviews with industry leaders and } \\
\text { researchers on mobile banking }\end{array}$ \\
\hline $\begin{array}{c}\text { Shrivastava } \\
\text { (2010): } \\
\text { South Africa }\end{array}$ & $\begin{array}{l}\text { To test } \\
\text { attitudes } \\
\text { towards mobile } \\
\text { financial } \\
\text { services, } \\
\text { including } \\
\text { mobile banking }\end{array}$ & - TAM & $\begin{array}{l}\text { - } 400 \text { questionnaire respondents } \\
\text { - Respondents' ages: } 42 \% \text { aged 25-34 }\end{array}$ \\
\hline
\end{tabular}




\begin{tabular}{|c|c|c|c|}
\hline $\begin{array}{l}\text { Author(s) } \\
\text { (year): } \\
\text { Country(ies), } \\
\text { region }\end{array}$ & $\begin{array}{l}\text { Objective(s), } \\
\text { research } \\
\text { question(s) }\end{array}$ & $\begin{array}{l}\text { Theories, } \\
\text { models }\end{array}$ & Data collection \\
\hline $\begin{array}{l}\text { Asongu } \\
\text { (2018): } 49 \\
\text { African } \\
\text { countries }\end{array}$ & $\begin{array}{l}\text { - To investigate } \\
\text { determinants of } \\
\text { mobile banking } \\
\text { adoption in } 49 \\
\text { Sub-Saharan } \\
\text { African } \\
\text { countries }\end{array}$ & $\begin{array}{l}\text { - Principal } \\
\text { component } \\
\text { analysis }\end{array}$ & $\begin{array}{l}\text { Data on variables-macroeconomic, } \\
\text { business/bank, market-related, } \\
\text { knowledge economy, external flows } \\
\text { and human development-collected } \\
\text { to investigate determinants of mobile } \\
\text { phone/banking in } 49 \text { Sub-Saharan } \\
\text { African countries }\end{array}$ \\
\hline $\begin{array}{l}\text { Van Deventer, } \\
\text { De Klerk and } \\
\text { Bevan-Dye } \\
\text { (2017): } \\
\text { South Africa }\end{array}$ & $\begin{array}{l}\text { To study the } \\
\text { influence of } \\
\text { perceived } \\
\text { integrity of } \\
\text { banks, and } \\
\text { perceived } \\
\text { system quality } \\
\text { of mobile } \\
\text { banking, among } \\
\text { Generation Y } \\
\text { students in the } \\
\text { South African } \\
\text { context }\end{array}$ & - Not specified & $\begin{array}{l}\text { - } 334 \text { questionnaire respondents } \\
\text { - Respondents' gender: M (42\%), F } \\
(58 \%)\end{array}$ \\
\hline $\begin{array}{l}\text { Mlitwa and } \\
\text { Tshetsha } \\
\text { (2012): } \\
\text { South Africa }\end{array}$ & $\begin{array}{l}\text { - To explore the } \\
\text { understanding } \\
\text { of mobile } \\
\text { banking } \\
\text { by rural } \\
\text { communities in } \\
\text { South Africa }\end{array}$ & - Not specified & $\begin{array}{l}\text { Interviews with } 10 \text { men and } 10 \\
\text { women in Gugulethu and Nyanga } \\
\text { townships, greater Cape Town, } \\
\text { Western Cape Province }\end{array}$ \\
\hline $\begin{array}{l}\text { Baptista } \\
\text { and Oliveira } \\
(2015): \\
\text { Mozambique }\end{array}$ & $\begin{array}{l}\text { To determine } \\
\text { the impact } \\
\text { of cultural } \\
\text { moderators on } \\
\text { behavioural } \\
\text { intention to } \\
\text { adopt mobile } \\
\text { banking }\end{array}$ & $\bullet$ UTAUT 2 & - 252 questionnaire respondents \\
\hline
\end{tabular}




\section{Findings and analysis: Challenges, benefits, and adoption dynamics}

\section{Challenges}

Poor mobile connectivity

Findings from six of the studies-examining conditions in Nigeria, Zimbabwe, Sudan, Rwanda, Ghana and South Africa-cite poor network infrastructure as the predominant barrier to people at the BOP embracing mobile banking (Ammar \& Ahmed, 2016; Asongu, 2018; Hinson, 2011; Mago \& Chitokwindo, 2014; Mlitwa \& Tshetsha, 2012; Shrivastava, 2010). Poor cellular network coverage in rural areas limits people's access to financial and banking services over the mobile devices. Mobile signals in rural areas often negatively affect the quality of communication when performing mobile banking transactions. This is due to the fact that cellular companies tend not to prioritise signal quality for people in the rural areas, as rural areas, because of their lower population densities and lower incomes, tend not to be as profitable as urban areas for mobile operators. As a result, many people in rural areas who live very far away from the cellular towers experience poor mobile signals.

\section{Lack of awareness of mobile banking services}

Six studies cite the lack of awareness as undermining mobile banking at the BOP (Ammar \& Ahmed, 2016; Baptista \& Oliveira, 2015; Chukwumah, 2017; Hinson, 2011; Mlitwa \& Tshetsha, 2012; Van der Wansem, 2013). Awareness also has an influence on the number of people who own bank accounts. Lack of awareness of mobile banking services is the second major barrier in adopting mobile banking. People who are not aware enough of the interface design, navigation, and contents of mobile applications lack the confidence to use mobile banking services.

\section{Illiteracy}

Four studies-looking at Sudan, Nigeria, South Africa and Ghana-highlight the fact that high illiteracy levels are a barrier to utilising mobile banking services (Ammar \& Ahmed, 2016; Bankole \& Cloete, 2011; Hinson, 2011; Mlitwa \& Tshetsha, 2012). Due to high illiteracy levels in many parts of Africa, particularly in rural areas, many people at the BOP are not able to fully understand and interpret mobile banking services. It was found that people who are literate more easily appreciate the notion of mobile banking and are more likely to be aware of at least basic mobile banking services.

\section{Poverty}

Poverty is a contributing factor, because lack of regular income makes it a challenge for people at the BOP to open an account. Some banks require a customer to have an initial deposit when opening an account, and then there are transaction costs incurred once the account is open (Chukwumah, 2017; Hinson, 2011; Mago \& Chitokwindo, 2014; Tchouassi, 2012). 


\section{Lack of trust due to perceived security risks}

Four studies cite lack of trust in mobile banking as a barrier to utilisation mobile banking services (Chukwumah, 2017; Mlitwa \& Tshetsha, 2012; Tchouassi, 2012; van Deventer, de Klerk, \& Bevan-Dye, 2017). A key reason for this lack of trust is the perception of risks associated with mobile banking, e.g., fear of security threats, such as fraud, that can occur during mobile banking.

\section{Legal and regulatory frameworks}

One study cites lack of mobile phone banking policies for the rural people as a barrier (Mtambalika et al., 2016), evidence that some challenges are created by lack of legal and regulatory frameworks.

\section{Cultural factors}

One study (Baptista \& Oliveira, 2015) identifies a range of more subtle, cultural factors that can hinder update of mobile banking at the BOP, such as unwillingness to accept change, uncertainty avoidance, and perceived power imbalances between users and banking operators, all of which can be cultural moderators in relation to adoption of mobile banking (Baptista \& Oliveira, 2015). The study based in Rwanda (Van der Wansem, 2013) shows that some men do not permit their wives to own mobile phones, thus presenting a clear gender barrier to mobile banking uptake.

\section{Benefits}

\section{Convenience and accessibility}

Nine of the studies provide findings to suggest that convenient and accessible banking services, for both low- and high-income people, are the major benefit of embracing mobile banking (Baptista \& Oliveira, 2015; Mago \& Chitokwindo, 2014; Mlitwa \& Tshetsha, 2012; Mtambalika et al., 2016; Shrivastava, 2010; Van der Wansem, 2013; Van Deventer et al., 2017). Three of those nine studies focus on the fact that mobile banking reduces time and access barriers (Chukwumah, 2017; Shrivastava, 2010; Van der Wansem, 2013). The Zimbabwe study provides the finding that $79 \%$ of the surveyed people indicated that mobile banking provides accessibility benefits (Mago \& Chitokwindo, 2014; Tchouassi, 2012; van Deventer et al.).

\section{Reduced handling of cash}

The Van der Wansem (2013) study provides the finding that mobile banking provides better financial security since it reduces the handling of cash.

\section{Promotion of financial inclusion}

The findings from three studies—conducted in Malawi, Rwanda Sudan-reveal mobile banking's role in increasing the uptake of banking services, thereby promoting financial inclusion (Ammar \& Ahmed, 2016; Mtambalika et al., 2016; Van der Wansem, 2013). 


\section{Reduced urban-rural divide}

The findings from Malawi, Rwanda Sudan studies reveal mobile banking's role in reducing the rural-urban divide (Ammar \& Ahmed, 2016; Mtambalika et al., 2016; Van der Wansem, 2013).

\section{Reduced inequality and poverty}

The findings from the study in Ghana show an improvement in the economic wellbeing of people who use mobile banking (Hinson, 2011). Findings from three other studies-across 49 countries (Asongu, 2018), in Nigeria (Chukwumah, 2017), and in Zimbabwe (Mago \& Chitokwindo, 2014) reveal mobile banking's ability to reduce inequality and poverty levels by creating new opportunities for the poor.

\section{Adoption dynamics}

\section{Technology adoption models}

As seen in Table 1, the two technology adoption models found most frequently across the studies are the aforementioned (in section 3):

- technology acceptance model (TAM); and

- unified theory of acceptance and use of technology (UTAUT).

Other models (also described in section 3) that we thought we might find deployed in the studies, but which are not present in the selected studies, are:

- innovation diffusion theory (IDT);

- the information system success model (ISSM);

- the task technology fit (TTF) model; and

- the theory of planned behaviour (TPB).

One model which appears in one of the studies, but which we did not anticipate finding, is the technology-organisation-environment (TOE) model (Tornatzky, Fleischer, \& Chakrabarti, 1990), which is deployed, with UTAUT, in the Ammar \& Ahmed (2016) Sudan study. Another of the studies employs a non-technologyadoption model, the contestable market theory (Boumol, Panzar, \& Willig, 1982), to determine how existing mobile banking agents can compete with others to offer better competitive mobile banking services to the people.

Four studies do not explicitly state the theory or model upon which the research is based.

\section{Perceived usefulness}

The findings from six of the studies highlight the key role of perceived usefulness in driving adoption of mobile technology (Ammar \& Ahmed, 2016; Baptista \& Oliveira, 2015; Chukwumah, 2017; Mago \& Chitokwindo, 2014; Mtambalika et al., 2016; Shrivastava, 2010). 


\section{Perceived ease of use}

Five studies provide findings that confirm the role of ease of use in driving mobile technology adoption (Ammar \& Ahmed, 2016; Baptista \& Oliveira, 2015; Mago \& Chitokwindo, 2014; Mtambalika et al., 2016; Shrivastava, 2010).

\section{Perceived convenience and accessibility}

Four of the studies indicate convenience and accessibility as other determining factors for adoption of mobile banking (Bankole \& Cloete, 2011; Chukwumah, 2017; Mago \& Chitokwindo, 2014; Van der Wansem, 2013).

\section{Cost}

Findings from four studies point to cost as a key factor guiding adoption or nonadoption of mobile technologies, including mobile banking (Ammar \& Ahmed, 2016; Chukwumah, 2017; Shrivastava, 2010; Van der Wansem, 2013).

\section{Security}

Four studies provide findings pointing to security as a major factor influencing adoption or non-adoption of mobile banking (Ammar \& Ahmed, 2016; Mago \& Chitokwindo, 2014; Mlitwa \& Tshetsha, 2012; Van der Wansem, 2013).

Other factors found to influence adoption of mobile banking are:

- perceived performance of mobile banking systems (Ammar \& Ahmed, 2016; Baptista \& Oliveira, 2015);

- effort required to use mobile banking (Ammar \& Ahmed, 2016);

- credibility (Ammar \& Ahmed, 2016; Shrivastava, 2010);

- perceived privacy (Ammar \& Ahmed, 2016);

- social influences (Ammar \& Ahmed, 2016; Bankole \& Cloete, 2011);

- needs or benefits from using mobile banking (Ammar \& Ahmed, 2016; Van der Boor et al., 2014);

- integrity (Van Deventer et al., 2017);

- age and gender (Tchouassi, 2012; Van der Boor et al., 2014);

- awareness (Bankole \& Cloete, 2011; Mlitwa \& Tshetsha, 2012);

- availability of information and communication technology (ICT) products and services (Tchouassi, 2012; Van der Boor et al., 2014); and

- cultural dynamics (Bankole \& Cloete, 2011; Van der Boor et al., 2014).

Table 2, provided over the next four pages (pp. 39-42), summarises the key findings, from the 14 studies, in respect of challenges, benefits, and adoption dynamics of mobile banking at the BOP in Africa. 
Table 2: Findings from the 14 studies

\begin{tabular}{|c|c|c|c|}
\hline $\begin{array}{c}\text { Author(s) } \\
\text { (year): } \\
\text { Country(ies), } \\
\text { region }\end{array}$ & Challenges & Benefits & Adoption dynamics \\
\hline $\begin{array}{c}\text { Chukwumah } \\
\text { (2017): } \\
\text { Nigeria }\end{array}$ & $\begin{array}{l}\text { - High levels of non- } \\
\text { awareness of mobile } \\
\text { banking in rural areas } \\
\text { e.g., } 20 \% \text { own a bank } \\
\text { account while } 86 \% \text { have } \\
\text { never heard of mobile } \\
\text { banking } \\
\text { - Many people in the rural } \\
\text { areas do not own bank } \\
\text { accounts } \\
\text { - Limited access to } \\
\text { internet } \\
\text { - Lack of trust in bank or } \\
\text { banking staff } \\
\text { - Fear of unsecure } \\
\text { transactions such as } \\
\text { fraud }\end{array}$ & $\begin{array}{l}\text { Mobile banking } \\
\text { reduces time and } \\
\text { access barriers to } \\
\text { banking services } \\
\text { - Mobile banking } \\
\text { makes accessing } \\
\text { banking services } \\
\text { affordable and } \\
\text { convenient }\end{array}$ & $\begin{array}{l}\text { - Perceived convenience } \\
\text { and trust found to have } \\
\text { a positive impact on } \\
\text { adoption of mobile } \\
\text { banking in the rural areas } \\
\text { - Perceived usefulness not } \\
\text { found to be significant, } \\
\text { since many people } \\
\text { preferred to keep money } \\
\text { at home } \\
\text { - Affordability of mobile } \\
\text { banking services, such as } \\
\text { alerts, found to influence } \\
\text { adoption }\end{array}$ \\
\hline $\begin{array}{c}\text { Mago and } \\
\text { Chitokwindo } \\
\text { (2014): } \\
\text { Zimbabwe }\end{array}$ & $\begin{array}{l}\text { - Inaccessibility due to } \\
\text { limited cellular network } \\
\text { connectivity for mobile } \\
\text { telephony and mobile } \\
\text { internet } \\
\text { - High mobile data prices } \\
\text { - Perceived insecurity of } \\
\text { online transactions }\end{array}$ & $\begin{array}{l}\text { - } 79 \% \text { feel mobile } \\
\text { banking benefits } \\
\text { people } \\
\text { Mobile banking: } \\
\text { - reduces transport } \\
\text { costs } \\
\text { - is easily } \\
\text { accessible to both } \\
\text { low- and high- } \\
\text { income people } \\
\text { - is easy to use } \\
\text { - is affordable }\end{array}$ & $\begin{array}{l}\text { Perceived ease of use, } \\
\text { security, convenience, and } \\
\text { accessibility all found to } \\
\text { influence adoption of } \\
\text { mobile banking }\end{array}$ \\
\hline $\begin{array}{c}\text { Ammar } \\
\text { and Ahmed } \\
\text { (2016): } \\
\text { Sudan }\end{array}$ & $\begin{array}{l}\text { - Lack of awareness of } \\
\text { mobile banking ( } 48 \% \\
\text { were unaware of mobile } \\
\text { banking) } \\
\text { - Perceived high financial } \\
\text { costs in using mobile } \\
\text { banking } \\
\text { - Limited innovation of } \\
\text { mobile banking products } \\
\text { and services } \\
\text { - Customer illiteracy } \\
\text { - Limited cellular network } \\
\text { connectivity for both } \\
\text { mobile telephony and } \\
\text { mobile internet }\end{array}$ & $\begin{array}{l}\text { Better access to } \\
\text { financial services }\end{array}$ & $\begin{array}{l}\text { - Performance expectancy } \\
\text { (perceived usefulness) } \\
\text { identified by } 77 \% \text { of } \\
\text { respondents, effort } \\
\text { expectancy (perceived } \\
\text { ease of use) by } 72 \% \text {, and } \\
\text { perceived credibility } \\
\text { (security and privacy) } \\
\text { by } 71 \% \text {-all of which } \\
\text { were found to affect } \\
\text { the adoption of mobile } \\
\text { banking } \\
\text { - Social influence, perceived } \\
\text { financial cost, and banking } \\
\text { found not to influence } \\
\text { the adoption of mobile } \\
\text { banking }\end{array}$ \\
\hline
\end{tabular}




\begin{tabular}{|c|c|c|c|}
\hline $\begin{array}{c}\text { Author(s) } \\
\text { (year): } \\
\text { Country(ies), } \\
\text { region }\end{array}$ & Challenges & Benefits & Adoption dynamics \\
\hline $\begin{array}{l}\text { Van der } \\
\text { Wansem } \\
\text { (2013): } \\
\text { Rwanda }\end{array}$ & $\begin{array}{l}\text { - Mobile phones not } \\
\text { affordable to many } \\
\text { people } \\
\text { - Limited cellular network } \\
\text { coverage for both mobile } \\
\text { telephony and mobile } \\
\text { internet } \\
\text { - Little knowledge of how } \\
\text { to use phones for mobile } \\
\text { banking } \\
\text { - Cultural values, as some } \\
\text { men do not allow women } \\
\text { to own phones } \\
\text { Elderly people have little } \\
\text { interest in using phones } \\
\text { for mobile banking }\end{array}$ & $\begin{array}{l}\text { - Time savings and } \\
\text { convenience of } \\
\text { access } \\
\text { - Better } \\
\text { accessibility } \\
\text { - Security and } \\
\text { reduced cash } \\
\text { handling } \\
\text { - Better customer } \\
\text { service } \\
\text { experience }\end{array}$ & $\begin{array}{l}\text { - Perceived challenges, such } \\
\text { as security, accessibility, } \\
\text { financial cost and trust, } \\
\text { found to influence } \\
\text { adoption of mobile } \\
\text { banking } \\
\text { - Perceived benefits, such } \\
\text { as time-saving and } \\
\text { convenience of access, } \\
\text { found to influence } \\
\text { adoption }\end{array}$ \\
\hline $\begin{array}{c}\text { Bankole and } \\
\text { Cloete (2011): } \\
\text { South Africa, } \\
\text { Nigeria }\end{array}$ & $\begin{array}{l}\text { - Security the major } \\
\text { concern }\end{array}$ & $\begin{array}{l}\text { - Not specifically } \\
\text { quantified }\end{array}$ & $\begin{array}{l}\text { - Cultural differences in } \\
\text { birth countries found to } \\
\text { influence adoption of } \\
\text { mobile banking } \\
\text { - Awareness, convenience } \\
\text { and literacy level found to } \\
\text { impact adoption } \\
\text { - Social factors found to } \\
\text { influence adoption in } \\
\text { South Africa, but not in } \\
\text { Nigeria }\end{array}$ \\
\hline $\begin{array}{c}\text { Mtambalika, } \\
\text { Manda, } \\
\text { Gombachika } \\
\text { and Kunyenje } \\
\text { (2016): } \\
\text { Malawi }\end{array}$ & $\begin{array}{l}\text { - Security concerns } \\
\text { - Lack of mobile banking } \\
\text { policies to support and } \\
\text { target rural people } \\
\text { - Lack of mobile banking } \\
\text { regulation framework }\end{array}$ & $\begin{array}{l}\text { - Banks reach out } \\
\text { to more people at } \\
\text { the BOP } \\
\text { - Customers not } \\
\text { required to visit } \\
\text { bank branches }\end{array}$ & $\begin{array}{l}\text { Perceived ease of use, } \\
\text { perceived usefulness, } \\
\text { presence of mobile } \\
\text { network and retail agents } \\
\text { found to influence } \\
\text { behavioural intention to } \\
\text { use the bank-led mobile } \\
\text { banking model }\end{array}$ \\
\hline $\begin{array}{c}\text { Hinson } \\
\text { (2011): } \\
\text { Ghana, Africa }\end{array}$ & $\begin{array}{l}\text { - Long geographical } \\
\text { distances to access } \\
\text { banking services, } \\
\text { including opening a bank } \\
\text { account } \\
\text { - Bureaucratic nature of } \\
\text { banking services prompt } \\
\text { people to shun banks } \\
\text { - High illiteracy levels } \\
\text { - Low awareness levels } \\
\text { in relation to mobile } \\
\text { banking }\end{array}$ & $\begin{array}{l}\text { - Improved } \\
\text { economic well- } \\
\text { being } \\
\text { - Improved } \\
\text { remittance flows } \\
\text { - Decreased } \\
\text { information } \\
\text { asymmetry }\end{array}$ & - Not specifically stated \\
\hline
\end{tabular}




\begin{tabular}{|c|c|c|c|}
\hline $\begin{array}{c}\text { Author(s) } \\
\text { (year): } \\
\text { Country(ies), } \\
\text { region }\end{array}$ & Challenges & Benefits & Adoption dynamics \\
\hline $\begin{array}{l}\text { Tchouassi } \\
\text { (2012): } \\
\text { 30 Sub- } \\
\text { Saharan } \\
\text { African } \\
\text { countries }\end{array}$ & $\begin{array}{l}\text { Poor network } \\
\text { infrastructure in rural } \\
\text { areas to support mobile } \\
\text { telephony and mobile } \\
\text { internet } \\
\text { - Lack of bank accounts } \\
\text { due to irregular income, } \\
\text { costs in maintaining } \\
\text { bank accounts, and lack } \\
\text { of trust in banks }\end{array}$ & $\begin{array}{l}\text { - New channel for } \\
\text { banking }\end{array}$ & $\begin{array}{l}\text { Rate of adoption found } \\
\text { to be influenced by: } \\
\text { availability of ICT } \\
\text { devices, income, age, } \\
\text { education, gender, family, } \\
\text { occupation, living place, } \\
\text { phone utilisation }\end{array}$ \\
\hline $\begin{array}{l}\text { Van der Boor, } \\
\text { Oliveira and } \\
\text { Veloso (2014): } \\
\text { Zambia, } \\
\text { Kenya }\end{array}$ & - Not specifically stated & $\begin{array}{l}\text { - Users benefit } \\
\text { a lot from } \\
\text { innovation of } \\
\text { mobile banking } \\
\text { if they are } \\
\text { fully involved } \\
\text { in developing } \\
\text { technological } \\
\text { products and } \\
\text { services service } \\
\text { innovators } \\
\text { - Users in } \\
\text { developing } \\
\text { countries are an } \\
\text { important source } \\
\text { of innovation in } \\
\text { mobile banking, } \\
\text { contributing } \\
\text { to 50\% of } \\
\text { innovations }\end{array}$ & $\begin{array}{l}\text { Factors contributing to } \\
\text { innovation are: } \\
\text { - Increasing access to ICT } \\
\text { - Flexible platforms } \\
\text { - Increasing client need to } \\
\text { transact and communicate } \\
\text { globally }\end{array}$ \\
\hline $\begin{array}{c}\text { Shrivastava } \\
\text { (2010): } \\
\text { South Africa }\end{array}$ & $\begin{array}{l}\text { - Limited access to mobile } \\
\text { banking services due to } \\
\text { poor cellular network } \\
\text { connectivity for mobile } \\
\text { telephony and mobile } \\
\text { internet } \\
\text { Low level of ownership } \\
\text { of bank accounts }\end{array}$ & $\begin{array}{l}\text { - Time saving } \\
\text { through not } \\
\text { traveling to } \\
\text { banks } \\
\text { - Reduced } \\
\text { transport costs } \\
\text { - Mobile banking } \\
\text { support for } \\
\text { communication } \\
\text { and financial } \\
\text { transactions in } \\
\text { health, farming }\end{array}$ & $\begin{array}{l}\text { Mobile banking adoption } \\
\text { found to be impacted } \\
\text { by perceived usefulness, } \\
\text { ease of use, credibility, } \\
\text { self-efficacy, financial } \\
\text { cost, enhanced image of } \\
\text { mobile banking users, and } \\
\text { perceived improvement } \\
\text { of life } \\
\text { - Perceived usefulness found } \\
\text { to have the strongest } \\
\text { influence on mobile } \\
\text { banking adoption }\end{array}$ \\
\hline $\begin{array}{l}\text { Asongu } \\
\text { (2018): } \\
\text { 49 African } \\
\text { countries }\end{array}$ & $\begin{array}{l}\text { - Uneven development } \\
\text { in terms of internet } \\
\text { penetration versus } \\
\text { mobile phone } \\
\text { penetration }\end{array}$ & $\begin{array}{l}\text { - Reduction of } \\
\text { the rural/urban } \\
\text { divide } \\
\text { - Financial } \\
\text { inclusion in the } \\
\text { rural areas }\end{array}$ & $\begin{array}{l}\text { Positive correlation found } \\
\text { between mobile banking } \\
\text { and trade openness, } \\
\text { internet penetration, } \\
\text { human development, } \\
\text { patent applications }\end{array}$ \\
\hline
\end{tabular}




\begin{tabular}{|c|c|c|c|}
\hline $\begin{array}{l}\text { Author(s) } \\
\text { (year): } \\
\text { Country(ies), } \\
\text { region }\end{array}$ & Challenges & Benefits & Adoption dynamics \\
\hline $\begin{array}{l}\text { Van Deventer, } \\
\text { De Klerk and } \\
\text { Bevan-Dye } \\
\text { (2017): } \\
\text { South Africa }\end{array}$ & $\begin{array}{l}\text { Perceived risk and } \\
\text { uncertainty in using } \\
\text { mobile banking } \\
\text { Perceived lack of system } \\
\text { quality, e.g., for provision } \\
\text { of accurate and relevant } \\
\text { information }\end{array}$ & $\begin{array}{l}\text { Speedy access to } \\
\text { mobile banking } \\
\text { services }\end{array}$ & $\begin{array}{l}\text { Trust in using mobile } \\
\text { banking services found to } \\
\text { be positively associated } \\
\text { with integrity and system } \\
\text { quality }\end{array}$ \\
\hline $\begin{array}{l}\text { Mlitwa and } \\
\text { Tshetsha } \\
\text { (2012): } \\
\text { South Africa }\end{array}$ & $\begin{array}{l}\text { - Lack of awareness } \\
\text { - Limited cellular } \\
\text { connectivity for mobile } \\
\text { telephony and mobile } \\
\text { internet } \\
\text { - Low literacy levels } \\
\text { - Lack of trust in mobile } \\
\text { banking } \\
\text { - Security threats }\end{array}$ & $\begin{array}{l}\text { - Saves time } \\
\text { instead of } \\
\text { travelling to the } \\
\text { bank } \\
\text { - Saves transport } \\
\text { costs } \\
\text { - Ubiquitous } \\
\text { access to the } \\
\text { banking services } \\
\text { at any time }\end{array}$ & $\begin{array}{l}\text { - Security concerns and } \\
\text { awareness of mobile } \\
\text { phone use found to } \\
\text { affect adoption of mobile } \\
\text { banking }\end{array}$ \\
\hline $\begin{array}{c}\text { Baptista } \\
\text { and Oliveira } \\
(2015): \\
\text { Mozambique }\end{array}$ & $\begin{array}{l}\text { - Many gradations of } \\
\text { acceptance of mobile } \\
\text { banking by clients due to } \\
\text { cultural values, usefulness } \\
\text { and ease of use of } \\
\text { the mobile banking } \\
\text { technology } \\
\text { - Lack of necessary skills } \\
\text { to use mobile banking }\end{array}$ & $\begin{array}{l}\text { - Increased access } \\
\text { to banking } \\
\text { services } \\
\text { - Mobile banking } \\
\text { is time and place } \\
\text { independent } \\
\text { - Banks reduce } \\
\text { operational costs } \\
\text { by embracing } \\
\text { mobile banking }\end{array}$ & $\begin{array}{l}\text { - Users'level of confidence } \\
\text { via getting benefits } \\
\text { from mobile banking } \\
\text { activities, users' level of } \\
\text { fun or pleasure from using } \\
\text { mobile banking, and users' } \\
\text { habits (such as results } \\
\text { from previous experiences } \\
\text { or frequency of any } \\
\text { past behaviour), impact } \\
\text { positively on behaviour } \\
\text { intention to adopt mobile } \\
\text { banking } \\
\text { - Collectivism, uncertainty } \\
\text { avoidance, short-termism } \\
\text { (people who expect quick } \\
\text { results easily adopt mobile } \\
\text { banking), and societal } \\
\text { power (if senior people } \\
\text { accept mobile banking, it } \\
\text { is likely to be accepted by } \\
\text { their subordinates) were } \\
\text { found to be significant } \\
\text { cultural moderators. }\end{array}$ \\
\hline
\end{tabular}




\section{Recommendations}

Our systematic review of 14 existing studies has managed to identify a range of compelling existing findings-as outlined and analysed in the previous section of this article-in respect of challenges, benefits, and adoption dynamics of mobile banking at the BOP in Africa. In this section we offer, based on the existing findings, recommendations for improved implementation of mobile banking at the $\mathrm{BOP}$ on the continent.

\section{An enabling, competitive environment for mobile banking}

Policymakers need to strive to create an enabling, competitive environment for mobile banking services among all key stakeholders such as telecom operators, internet providers, banks, and non-governmental organisations. Competition among players can be expected to encourage adoption of technologies and platforms that provide accessible, affordable, open, and safe mobile banking services to consumers.

\section{Partnerships among key stakeholders}

There need to be partnerships among certain key stakeholders in support of elements necessary for increased mobile banking takeup at the BOP in Africa. For example, stakeholder collaboration is needed in support of increased access to, and adoption of, mobile internet connectivity. Stakeholders must also work together to formulate and implement policies and strategies that support financial literacy; mobile banking user education; and development of relevant, customisable and user-friendly interfaces. The overall goal of partnerships needs to be the development of accountable and transparent mobile banking ecosystems in Africa that are characterised by innovation, efficiency and inclusion.

\section{Ease of opening bank accounts}

Initiatives need to be formulated to make it increasingly straightforward for a new customer to open a bank account. Many banks require that new accounts must have a minimum opening balance, and that account-holders must maintain a minimum balance - two requirements that must be reviewed and revised, because they are barriers to many people at the BOP in Africa.

\section{Awareness-raising}

Governments and other key stakeholders need to work together to build awareness of mobile banking services. Specifically, awareness campaigns need to address the cultural factors highlighted by this review: unwillingness to accept change, uncertainty avoidance, perceived power imbalances between users and banking operators, and gender-based barriers. In addition, in order to enhance trust in mobile banking services, stakeholders need to make sure that customers are aware of, and protected as much as possible against, cybersecurity vulnerabilities and threats. 


\section{Infrastructure use and development}

Banks need to use the already existing mobile networks to offer mobile banking to rural, unbanked people. Since it is proven that ICT infrastructure positively impacts on the success of the adoption of mobile banking, all key stakeholders must collaborate to improve the network availability and infrastructure. Deliberate initiatives must be set up to sustain high levels of ICT expertise.

\section{Consumer/user focus}

There is a need for policymakers, company managers and system developers to embrace more customer-centric approaches when implementing mobile banking solutions, in order to make mobile banking applications more user-friendly for people at the BOP in Africa. In particular, greater attention needs to be paid to the needs of rural people who are illiterate or only partially literate, and/or people who can only speak and/or read a minority language. It is recommended that mobile banking interfaces gradually be developed in all of the languages spoken on the continent, and that the interfaces provide the option of verbal-only interaction for those who cannot read and write.

\section{Policy, law and regulation}

African governments need to set up retail banking policies that allow mobile network operators to start directly offering mobile banking services. Key players in the mobile banking sector must work together to set up legal and regulatory frameworks that, among other things, generate standards for interoperability of various mobile banking application platforms, and ensure security controls to address the security, privacy and confidentiality concerns of the users. It is also important to ensure that laws and policies governing both the digital infrastructure and retail banking are not too strict but also flexible enough so that innovation and competition of mobile banking services can be enhanced.

\section{Conclusion}

This systematic review has identified perceived challenges that hamper the adoption of mobile banking by people at the BOP in Africa, including poor mobile internet connectivity; lack of awareness of mobile banking services; illiteracy; poverty; lack of trust due to perceived security risks; lack of legal and regulatory frameworks in support of mobile banking; and cultural factors.

The review has also identified perceived benefits of mobile banking among people at the BOP in Africa, including convenience and accessibility; reduced handling of cash; increased financial inclusion; reduction of the urban-rural divide; and reduced inequality and poverty.

Furthermore, this review has identified a variety of dynamics impacting upon adoption of mobile banking by people at the BOP in Africa, including perceived 
usefulness; perceived ease of use; perceived convenience and accessibility; cost; security; perceived performance of mobile banking systems; perceived privacy; social influences; perceived needs and benefits from use of mobile banking; perceived mobile banking integrity and system quality; awareness; availability of ICT products and services; and cultural dynamics.

Finally, we provided recommendations for improved implementation of mobile banking in Africa, in the following categories: an enabling, competitive environment; partnerships among key stakeholders; ease of opening bank accounts; awarenessraising; infrastructure use and development; consumer/user focus; and policy, law and regulation.

It must be noted that, in our systematic review, we focused exclusively on African contexts in respect of challenges, benefits, and adoption dynamics of mobile banking for people at BOP. A broader systematic review, spanning across a wider range of developing-world contexts including contexts outside Africa, would be of great value - in order to broaden the understanding of how mobile technologies can facilitate affordable access to banking products for the world's most vulnerable groups.

\section{References}

Ajzen, I. (1985). From intentions to actions: A theory of planned behavior. In J. Kuhl, \& J. Beckmann (Eds.), Action control (pp. 11-39). Berlin: Springer. https://doi.org/10.1007/978-3-642-69746-3_2

Alafeef, M., Singh, D., \& Ahmad, K. (2012). The influence of demographic factors and user interface on mobile banking adoption: A review. Journal of Applied Sciences, 12(20), 2082-2095. https://doi.org/10.3923/jas.2012.2082.2095

Ammar, A., \& Ahmed, E. M. (2016). Factors influencing Sudanese microfinance intention to adopt mobile banking. Cogent Business \& Management, 3(1), 1-20. https://doi.org/10.1080/23311975.2016.1154257

Asongu, S. A. (2018). Conditional determinants of mobile phones penetration and mobile banking in Sub-Saharan Africa. Journal of the Knowledge Economy, 9(1), 81-135. https://doi.org/10.1007/s13132-015-0322-z

Bankole, O., \& Cloete, E. (2011). Mobile banking: A comparative study of South Africa and Nigeria. Paper presented at IEEE Africon '11, Livingstone, Zambia. https://doi.org/10.1109/AFRCON.2011.6072178

Baptista, G., \& Oliveira, T. (2015). Understanding mobile banking: The unified theory of acceptance and use of technology combined with cultural moderators. Computers in Human Behavior, 50, 418-430. https://doi.org/10.1016/j.chb.2015.04.024

Beck, T., \& Cull, R. (2013). Banking in Africa. Policy Research Working Paper 6684. Washington, DC: World Bank. https://doi.org/10.1596/1813-9450-6684

Baumol, W. J., Panzar, J. C., \& Willig, R. D. (1982). Contestable markets and the theory of industry structure. San Diego. CA: Harcourt Brace Jovanovich. 
Brown, I., Cajee, Z., Davies, D., \& Stroebel, S. (2003). Cell phone banking: Predictors of adoption in South Africa - an exploratory study. International Journal of Information Management, 23(5), 381-394. https://doi.org/10.1016/S0268-4012(03)00065-3

Chavan, J. (2013). Internet banking - benefits and challenges in an emerging economy. International Journal of Research in Business Management, 1(1), 19-26.

Chukwumah, S. (2017). Adoption of mobile banking in rural Nigeria. Master's thesis, University of Turku, Finland.

Davis, F. D. (1989). Perceived usefulness, perceived ease of use, and user acceptance of information technology. MIS Quarterly, 13(3), 319-340. https://doi.org/10.2307/249008

Demirgüç-Kunt, A., Klapper, L., Singer, D., Ansar. S., \& Hess, J. (2017). Global findex database 2017: Measuring financial inclusion and the fintech revolution. Washington, DC: World Bank. https://doi.org/10.1596/978-1-4648-1259-0

DeLone, W. H., \& McLean, E. R. (2003). The DeLone and McLean model of information systems success: A ten-year update. Journal of Management Information Systems, 19(4), 9-30. https://doi.org/10.1080/07421222.2003.1104574.8

Gebauer,J., \& Shaw, M.J. (2004). Success factors and impacts of mobile business applications: Results from a mobile e-procurement study. International Journal of Electronic Commerce, 8(3), 19-41. https://doi.org/10.1080/10864415.2004.11044304

Goodhue, D. L., \& Thompson, R. L. (1995). Task-technology fit and individual performance. MIS Quarterly, 19(2), 213-236. https://doi.org/10.2307/249689

GSM Association (GSMA). (2016). The mobile economy: Africa 2016. London: GSMA.

GSMA. (2018a). The mobile economy 2018. London: GSMA.

GSMA. (2018b). The mobile economy: Sub-Saharan Africa 2018. London: GSMA. Retrieved from https://www.gsma.com/mobileeconomy/sub-saharan-africa

GSMA. (2018c). The mobile economy: West Africa 2018. London: GSMA. Retrieved from https://www.gsma.com/mobileeconomy/west-africa/

GSMA. (2018d). The mobile economy: Middle East and North Africa 2018. London: GSMA. Retrieved https://www.gsma.com/mobileeconomy/mena/

Gu, J.-C., Lee, S.-C., \& Suh, Y.-H. (2009). Determinants of behavioral intention to mobile banking. Expert Systems with Applications, 36(9), 11605-11616. https://doi.org/10.1016/j.eswa.2009.03.024

Hinson, R. E. (2011). Banking the poor: The role of mobiles. Journal of Financial Services Marketing, 15(4), 320-333. https://doi.org/10.1057/fsm.2010.29

Im, I., Hong, S., \& Kang, M. S. (2011). An international comparison of technology adoption: Testing the UTAUT model. Information E Management, 48(1), 1-8. https://doi.org/10.1016/j.im.2010.09.001

Internet World Stats. (2018). The internet big picture: World internet users and 2018 population stats. Retrieved from https://www.internetworldstats.com/stats.htm

Ivatury, G., \& Mas, I. (2008). The early experience with branchless banking. Focus Note 46. Washington, DC: CGAP. 
Jolliffe, I. T. (2002). Principal component analysis (2nd ed.). New York: Springer. https://doi.org/10.1007/b98835

Kemp, S. (2017). Digital in 2017: Global overview. We Are Social and Hootsuite. Retrieved from https://wearesocial.com/special-reports/digital-in-2017-global-overview

Kemp, S. (2018). Digital in 2018. We Are Social and Hootsuite. Retrieved from https:// hootsuite.com/pages/digital-in-2018

Kopala, M. R. (2010). Mobile banking: A tool of financial inclusion for India. SSRN. http://dx.doi.org/10.2139/ssrn.1674328

Lee, K. C., \& Chung, N. (2009). Understanding factors affecting trust in and satisfaction with mobile banking in Korea: A modified DeLone and McLean's model perspective. Interacting with Computers, 21(5-6), 385-392. https://doi.org/10.1016/j.intcom.2009.06.004

Mago, S., \& Chitokwindo, S. (2014). The impact of mobile banking on financial inclusion in Zimbabwe: A case for Masvingo Province. Mediterranean Journal of Social Sciences, 5(9), 221-230. https://doi.org/10.5901/mjss.2014.v5n9p221

Majchrzak, A., Rice, R. E., Malhotra, A., King, N., \& Ba, S. (2000). Technology adaptation: The case of a computer-supported inter-organizational virtual team. MIS Quarterly, 24(4), 569-600. https://doi.org/10.2307/3250948

Mallat, N., Rossi, M., \& Tuunainen, V. K. (2004). Mobile banking services. Communications of the ACM, 47(5), 42-46. https://doi.org/10.1145/986213.986236

Mbiti, I., \& Weil, D. N. (2011). Mobile banking: The impact of M-Pesa in Kenya. Cambridge, MA: National Bureau of Economic Research. https://doi.org/10.3386/w17129

Mlitwa, N. B. W., \& Tshetsha, N. (2012). Adoption of cell-phone banking among low-income communities in rural areas of South Africa. iBusiness 4(4), 362-370. https://doi.org/10.4236/ib.2012.44045

Moher, D., Liberati, A., Tetzlaff, J., \& Altman, D. G. (2009). Preferred reporting items for systematic reviews and meta-analyses: The PRISMA statement. Annals of Internal Medicine, 151(4), 264-269.

https://doi.org/10.7326/0003-4819-151-4-200908180-00135

Moore, G. C., \& Benbasat, I. (1991). Development of an instrument to measure the perceptions of adopting an information technology innovation. Information Systems Research, 2(3), 192-222. https://doi.org/10.1287/isre.2.3.192

Morawczynski, O. (2009). Exploring the usage and impact of "transformational" mobile financial services: The case of M-PESA in Kenya. Journal of Eastern African Studies, 3(3), 509-525. https://doi.org/10.1080/17531050903273768

Mtambalika, A., Manda, T. D., Gombachika, H., \& Kunyenje, G. (2016). Branchless banking in rural Malawi: Potential customers' perspective on bank-led mobile banking. In P. Cunningham \& M. Cunningham (Eds.), IST-Africa 2016 conference proceedings. https://doi.org/10.1109/ISTAFRICA.2016.7530701

Nasri, W., \& Charfeddine, L. (2012). Factors affecting the adoption of Internet banking in Tunisia: An integration theory of acceptance model and theory of planned behavior. The Journal of High Technology Management Research, 23(1), 1-14. https://doi.org/10.1016/j.hitech.2012.03.001 
Oliveira, T., Faria, M., Thomas, M. A., \& Popovič, A. (2014). Extending the understanding of mobile banking adoption: When UTAUT meets TTF and ITM. International Journal of Information Management, 34(5), 689-703. https://doi.org/10.1016/j.ijinfomgt.2014.06.004

Porteous, D. (2006). The enabling environment for mobile banking in Africa. For UK Department for International Development (DFID). Retrieved from https:// www.microfinancegateway.org/sites/default/files/mfg-en-paper-the-enablingenvironment-for-mobile-banking-in-africa-may-2006 0.pdf

Prahalad, C. K. (2006). The fortune at the bottom of the pyramid: Eradicating poverty through profits. Upper Saddle River, NJ: Pearson Education. https://doi.org/10.1111/j.1468-0270.2008.864 4.x

Rammile, N., \& Nel, J. (2012). Understanding resistance to cell phone banking adoption through the application of the technology acceptance model (TAM). African Journal of Business Management, 6(1), 86-97. https://doi.org/10.5897/AJBM11.635

Rogers, E. (1995). Diffusion of innovations: Modifications of a model for telecommunications (4th ed.). New York: Free Press. https://doi.org/10.1007/978-3-642-79868-9 2

Shih, K.-H., Hung, H.-F., \& Lin, B. (2010). Assessing user experiences and usage intentions of m-banking service. International Journal of Mobile Communications, 8(3), 257277. https://doi.org/10.1504/IJMC.2010.032974

Shih, Y.-Y., \& Fang, K. (2004). The use of a decomposed theory of planned behavior to study internet banking in Taiwan. Internet Research, 14(3), 213-223. https://doi.org/10.1108/10662240410542643

Shrivastava, P. (2010). Build it - will they come? A study of the adoption of mobile financial services by low income clients in South Africa. Journal of Electronic Commerce in Organizations (JECO), 8(3), 1-14. https://doi.org/10.4018/jeco.2010070101

Tchouassi,G.(2012).Can mobile phones reallywork to extend bankingservices to the unbanked? Empirical lessons from selected Sub-Saharan Africa countries. International Journal of Developing Societies, 1(2), 70-81. https://doi.org/10.11634/21681783150489

Tobbin, P. (2012). Towards a model of adoption in mobile banking by the unbanked: A qualitative study. info, 14(5), 74-88. https://doi.org/10.1108/14636691211256313

Tornatzky, L. G., Fleischer, M., \& Chakrabarti, A. K. (1990). The processes of technological innovation. Lanham, MD: Lexington Books, Rowman and Littlefield.

Van der Boor, P., Oliveira, P., \& Veloso, F. (2014). Users as innovators in developing countries: The global sources of innovation and diffusion in mobile banking services. Research Policy, 43(9), 1594-1607. https://doi.org/10.1016/j.respol.2014.05.003

Van der Wansem, S. (2013). Financial inclusion: Banking on mobile phones? Master's dissertation, Wageningen University, The Netherlands. Retrieved from http:// edepot.wur.nl/317936 (871108-928040)

Van Deventer, M., De Klerk, N., \& Bevan-Dye, A. (2017). Influence of perceived integrity and perceived system quality on Generation Y students' perceived trust in mobile banking in South Africa. Banks and Bank Systems, 12(1), 128-134. http://dx.doi.org/10.21511/bbs.12(1-1).2017.05 
Venkatesh, V. (2000). Determinants of perceived ease of use: Integrating control, intrinsic motivation, and emotion into the technology acceptance model. Information Systems Research, 11(4), 342-365. https://doi.org/10.1287/isre.11.4.342.11872

Venkatesh, V., \& Bala, H. (2008). Technology acceptance model 3 and a research agenda on interventions. Decision Sciences, 39(2), 273-315. https://dx.doi.org/10.1111/j.1540-5915.2008.00192.x

Venkatesh, V., \& Davis, F. D. (1996). A model of the antecedents of perceived ease of use: Development and test. Decision Sciences, 27(3), 451-481. https://doi.org/10.1111/j.1540-5915.1996.tb00860.x

Venkatesh, V., Morris, M. G., Davis, G. B., \& Davis, F. D. (2003). User acceptance of information technology: Toward a unified view. MIS Quarterly, 27(3), 425-478. http://dx.doi.org/10.2307/30036540

World Bank. (n.d.). Financial inclusion. Retrieved from https://www.worldbank.org/en/ topic/financialinclusion

World Bank (2016). Poverty and shared prosperity 2016. Retrieved from http://www. worldbank.org/en/publication/poverty-and-shared-prosperity

World Bank. (2012). Information and communications for development 2012: Maximizing mobile. https://doi.org/10.1596/978-0-8213-8991-1

Yu, C. S. (2012). Factors affecting individuals to adopt mobile banking: Empirical evidence from the UTAUT model. Journal of Electronic Commerce Research, 13(2), 104-121. Retrieved from http://www.jecr.org/sites/default/files/13_3_p01_0.pdf

Zhou, T., Lu, Y., \& Wang, B. (2010). Integrating TTF and UTAUT to explain mobile banking user adoption. Computers in Human Behavior, 26(4), 760-767. https://doi.org/10.1016/j.chb.2010.01.013 